\title{
Linking the distribution of microbial deposits from the Great Salt Lake (Utah, USA) to tectonic and climatic processes
}

\author{
Anthony Bouton ${ }^{1}$, Emmanuelle Vennin ${ }^{1}$, Julien Boulle ${ }^{1}$, Aurélie Pace ${ }^{2}$, Raphaël Bourillot ${ }^{2}$, Christophe Thomazo ${ }^{1}$, \\ Arnaud Brayard $^{1}$, Guy Désaubliaux ${ }^{3}$, Tomasz Goslar ${ }^{4,5}$, Yusuke Yokoyama ${ }^{6}$, Christophe Dupraz ${ }^{7}$, and \\ Pieter T. Visscher ${ }^{8}$ \\ ${ }^{1}$ Laboratoire Biogéosciences UMR 6282 UBFC/CNRS, Univ. Bourgogne Franche-Comté, 6 boulevard Gabriel, \\ 21000 Dijon, France \\ ${ }^{2}$ Géoressources et Environnement, Ensegid, Institut Polytechnique de Bordeaux, EA 4592, Université de Bordeaux, \\ 1 allée Daguin, 33607 Pessac, France \\ ${ }^{3}$ GDF Suez, Exploration Production International, 1 place Samuel de Champlain, Faubourg de l'Arche, \\ 92930 Paris La Défense CEDEX, France \\ ${ }^{4}$ Adam Mickiewicz University, Faculty of Physics, Poznań, Poland \\ ${ }^{5}$ Poznań Radiocarbon Laboratory, Foundation of the Adam Mickiewicz University, Poznań, Poland \\ ${ }^{6}$ Atmosphere and Ocean Research Institute, Department of Earth and Planetary Sciences, University of Tokyo, \\ 5-1-5 Kashiwanoha, Chiba, 277-8564, Japan \\ ${ }^{7}$ Department of Geological Sciences, Stockholm University, Svante Arrhenius väg 8, 06269 Stockholm, Sweden \\ ${ }^{8}$ Department of Marine Sciences, University of Connecticut, 1080 Shennecossett Road, Groton, CT 06340, USA
}

Correspondence to: Anthony Bouton (anthony.bouton@u-bourgogne.fr)

Received: 16 December 2015 - Published in Biogeosciences Discuss.: 11 March 2016

Revised: 2 September 2016 - Accepted: 5 September 2016 - Published: 5 October 2016

\begin{abstract}
The Great Salt Lake is a modern hypersaline lake, in which an extended modern and ancient microbial sedimentary system has developed. Detailed mapping based on aerial images and field observations can be used to identify nonrandom distribution patterns of microbial deposits, such as paleoshorelines associated with extensive polygons or faultparallel alignments. Although it has been inferred that climatic changes controlling the lake level fluctuations explain the distribution of paleoshorelines and polygons, straight microbial deposit alignments may underline a normal fault system parallel to the Wasatch Front. This study is based on observations over a decimetre to kilometre spatial range, resulting in an integrated conceptual model for the controls on the distribution of the microbial deposits. The morphology, size and distribution of these deposits result mainly from environmental changes (i.e. seasonal to long-term water level fluctuations, particular geomorphological heritage, fault-induced processes, groundwater seepage) and have the potential to bring further insights into the reconstruction of paleoenvironments and paleoclimatic changes through time. New ra-
\end{abstract}

diocarbon ages obtained on each microbial macrofabric described in this study improve the chronological framework and question the lake level variations that are commonly assumed.

\section{Introduction}

Lacustrine microbialites have been linked to significant petroleum systems, especially prolific ones in the Lower Cretaceous "pre-salt" systems found offshore in Brazil and Angola (Davison, 2007; Mello et al., 2012). The discovery of extensive microbial deposits associated with petroleum reservoirs has increased the interest in modern and ancient microbialite analogs (Chidsey et al., 2015). The Great Salt Lake (GSL) shares numerous comparable geodynamical characteristics with pre-salt deposits (e.g. normal fault system framework, volcanic activity; Liu, 2001) and additionally shows a high diversity and abundance of lacustrine microbialites (e.g. Eardley, 1938). The GSL thus represents an 
appropriate modern analog for Lower Cretaceous and other petroleum systems, as well as microbially dominated lakes in general.

The GSL represents the last $11.5 \mathrm{kyr}$ phase of a long lake history initiated ca. $30 \mathrm{ka} \mathrm{BP}$ ago with the Lake Bonneville (LB) phase (Oviatt et al., 1992; Godsey et al., 2005). The first investigations into the GSL sedimentary record were performed by Eardley (1938), who extensively described its sediment lithology and distribution, including that of microbial deposits referred to as calcareous algal bioherms. Recent geophysical methods have expanded knowledge on these microbial deposits and provided a preliminary understanding of the factors controlling their spatio-temporal distribution, especially the active tectonic and anthropogenic effects (Baskin et al., 2011, 2012, 2013). Other studies have paved the way to describe the GSL microbial system in comprehensive and integrated models and focused on (i) how the growth pattern of the microbial deposits was influenced by physical (e.g. the geometry of the underlying substrate; Carozzi, 1962) and chemical (e.g. changes in water salinity under anthropogenic influence; Lindsay et al., 2016) parameters, (ii) the calcium carbonate precipitation processes (Halley, 1977; Post, 1980; Pedone and Folk, 1996), (iii) the petrography of the microbial deposits (Chidsey et al., 2015; Della Porta, 2015), and (iv) the adaptation of microbial organisms to this unstable and harsh environment (Baxter et al., 2005). However, the combination of detailed descriptions of both microbial and sedimentary structures and the evaluation of the factors controlling their distribution through the GSL temporal dynamics (e.g. water level fluctuations, tectonics) have been poorly investigated to date. Bridging the relationship between microbial deposits and the lacustrine dynamic is crucial for analysing the fossil record for paleoenvironmental reconstructions.

In the GSL environment, microbial deposits are composed of both microbial mats and microbialites. Microbial mats are organosedimentary structures, characterized by the presence of phototrophic bacteria and high microbial metabolic rates (Stal et al., 1985; van Gemerden, 1993). They form sedimentary ecosystems that consist of a diverse microbial community embedded in an organic biofilm matrix (Decho et al., 2000; Ley et al., 2006; Baumgartner et al., 2009). Microbial mats can mineralize either through trapping and binding detrital sediments and/or through microbially mediated precipitation (Burne and Moore, 1987; Dupraz et al., 2009). The resulting structures, called microbialites, can be preserved in the rock record (Dupraz et al., 2011).

Here, we focused on the western margin of Antelope Island, in the southeastern part of the GSL (Fig. 1). We mapped the spatio-temporal distribution of the microbial and nonmicrobial deposits as well as the sedimentary structures. Even if other microbial deposits ("tufa") have already been described for the Pleistocene LB (Felton et al., 2006), we focused on the well-developed and extended structures outcropping close to the modern-day water level. We relate the observed variations to the potential environmental (external) controlling parameters (i.e. bathymetry, shoreline migration, desiccation, hydrogeology). Finally, we discuss the influence of climate vs. tectonics on the formation, distribution and preservation of microbial deposits through time.

\section{Settings}

The GSL is an endorheic hypersaline lake located in northwestern Utah (USA; Fig. 1). It is part of the Basin and Range Province, which formed by the gravitational collapse of the North American Cordillera (Liu, 2001). The GSL surface area averages $4480 \mathrm{~km}^{2}$ (since at least 1876) with a maximal depth of $10 \mathrm{~m}$ (Baskin and Allen, 2005). The mean historical water level (MHWL) has been set at $1280 \mathrm{~m}$ a.s.l. (above sea level; from the GSL level record available from the US Geological Survey), which is used as the reference value in this study. The average salinity in the south arm of the GSL, where Antelope Island is located (Fig. 1), is approximately $120 \mathrm{~g} \mathrm{~L}^{-1}$ (from 1966 onwards) but shows an important range of fluctuations (from 50 to $285 \mathrm{~g} \mathrm{~L}^{-1}$ since 1966) resulting from the variations in the water volume (Rupke and McDonald, 2012). GSL water inputs come from rivers (66\%; Bear, Jordan and Weber-Ogden rivers), rainfall (31\%) and subsurface flow (3\%; Gwynn, 1996). As a closed-basin lake, the GSL water level reflects the balance between these inputs and net evaporation. On an annual scale, the seasonality of the inputs and evaporation induces an average of 0.3$0.6 \mathrm{~m}$ fluctuations in the lake level (Chidsey et al., 2015). On a longer timescale, the GSL water level is mainly under the control of pluri-metre scale climate-induced variations (Lall and Mann, 1995) resulting from the interplay between the climatic Pacific quasidecadal oscillation and the interdecadal Pacific oscillation (Wang and Gillies, 2012).

Modern fluctuations in the GSL level are in the same range as those estimated for its entire history (e.g. Murchison, 1989). However, the GSL only dates back to the last $11.5 \mathrm{kyr}$ and is the remnant of the LB phase (from ca. 30 to $11.5 \mathrm{ka} \mathrm{BP}$; Oviatt et al., 1992; Godsey et al., 2005) during which the fluctuations in the lake level were significantly higher. LB reached a maximal surface area of $52000 \mathrm{~km}^{2}$, with a corresponding maximal depth close to $372 \mathrm{~m}$ (Patrickson et al., 2010). During this period, the mass of water was considered sufficient (ca. $1.10^{16} \mathrm{~m}^{3}$ ) to isostatically weigh down the crust of the earth, thereby inducing a depression (Oviatt, 2015). The different water level falls following the LB highstand episode induce the consequent removal of the water load and generate an isostatic rebound of the crust to its original position (Oviatt, 2015). Therefore, the isostatic rebound affects the four main terraces differently; these are easily recognizable in the current landscape (Stansbury, Bonneville, Provo and Gilbert; Patrickson et al., 2010) and reflect the main lake level variations. Oviatt (2015) considered that the entire water level elevation below an altitude 

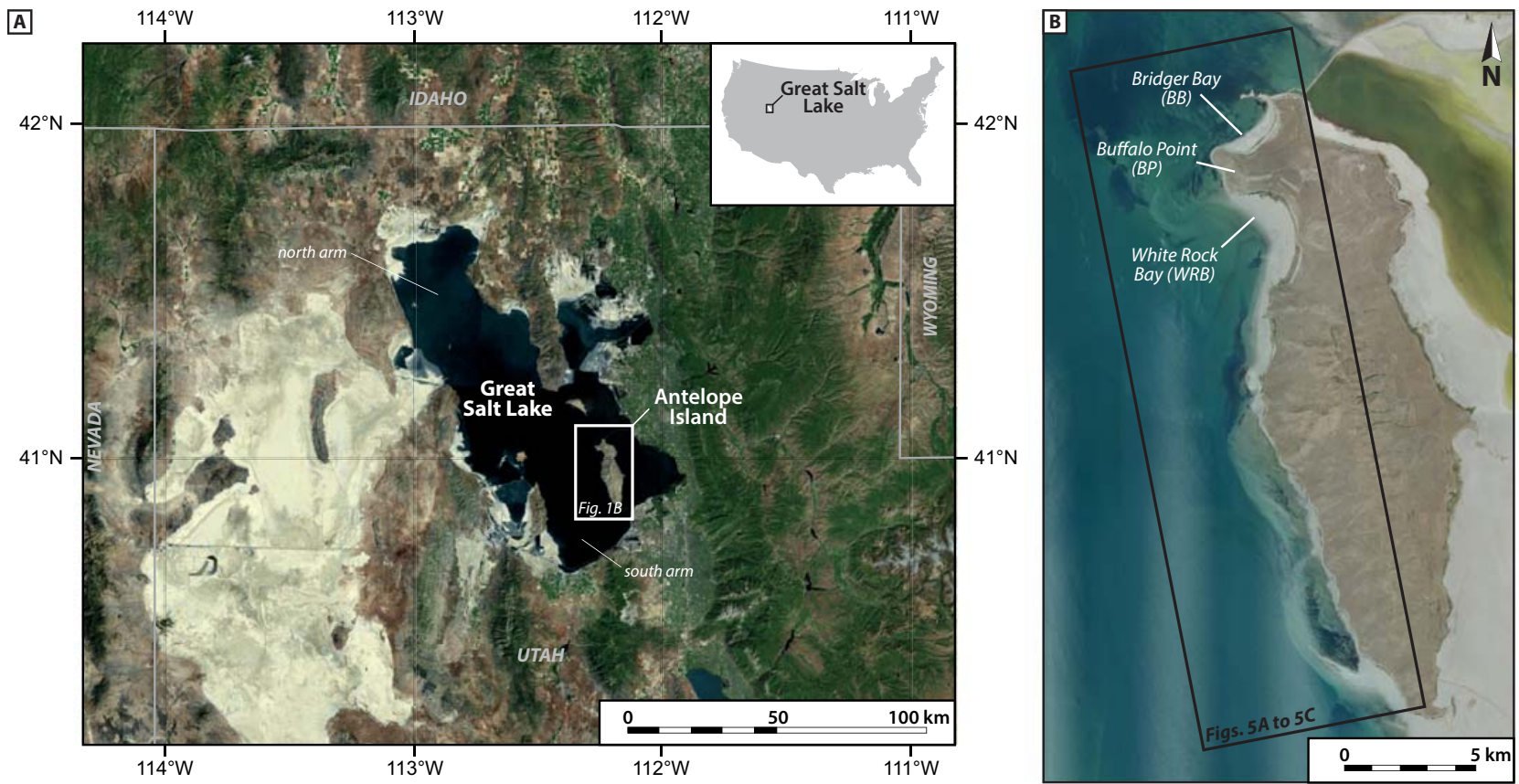

Figure 1. Satellite images of the Great Salt Lake (a) and Antelope Island (b) showing the studied localities: Bridger Bay (BB), Buffalo Point (BP) and White Rock Bay (WRB). The satellite images are provided by Flashearth (with Bing maps; Microsoft Corporation-Imagery ${ }^{\circledR}$ Harris Corp, Earthstar Geographics LLC) and the Utah Automated Geographic Reference Center (2014 NAIP 1 Meter Orthophotography).

of $1300 \mathrm{~m}$ a.s.l. (i.e. at or below the Gilbert shoreline) was not affected by the isostatic rebound and suggested that the post-Bonneville rebound ceased before the GSL phase at ca. $11.5 \mathrm{kaBP}$ (around $13 \mathrm{cal} \mathrm{ka)}$.

\section{Antelope Island: shore-to-lake transect and dating}

Ancient and recent microbial deposits, non-microbial deposits and sedimentary structures have been investigated along the western margin of Antelope Island to specify their distribution and understand the implied controlling factors. The first step consisted of a precise field determination and descriptions of the different sediments and their sedimentary structures recognized in the northwestern part of Antelope Island. This data set has been correlated with aerial images. This work is supported by detailed mapping and 12 transects from the shore up to $500 \mathrm{~m}$ lakeward, physical analysis in the field (e.g. pH and conductivity, microelectrodes measurements within recent microbial mats), and extensive sampling (ca. 500 samples, including microbial, nonmicrobial deposits and water), which allowed further laboratory analysis (e.g. optical and scanning electron microscopy, XRD). The detailed methodology for living microbial mats sampling, conservation and analysis is described in Pace et al. (2016). As the microbial deposits mainly developed along the shoreline area, the work is focused on this proximal area of the GSL (Fig. 2). The shoreline terminology is used to describe the boundary line between the lake water and the land.
Therefore, it is an ephemeral feature that constantly shifts in the vertical and horizontal position following changes in weather, climate, tectonics and geomorphic processes (Oviatt, 2014). The shore is considered to be the land along the edge of the lake and thus corresponds to an area that is usually emersed.

In order to estimate the duration of microbialite development and improve the chronology of the lake level variations, nine new radiocarbon ages of microbial structures and ooids are provided in this study. Ages were measured using accelerator mass spectrometers from the Atmosphere and Ocean Research Institute at the University of Tokyo (Yamane et al., 2014; sample preparation and analytical details are different depending on the sample size and are described in detail in Yokoyama et al., 2007, 2010) and the Adam Mickiewicz University in Poznań (Goslar et al., 2004; the samples were prepared in the Poznan Radiocarbon Laboratory before the analysis).

\subsection{Microbial deposits}

Microbial deposits extensively colonize the lake margin and show a heterogeneous spatial distribution and macrofabrics (Fig. 2). In addition to the domes (and columns) described by Della Porta (2015), four other macrofabrics can be distinguished along the shore-to-lake transect distributed both on emersed or recently submersed area. On the emersed shore, fossil microbialites (Fig. 3a, b), composed of carbonate minerals (aragonite and calcite, associated with dolomite in pore 

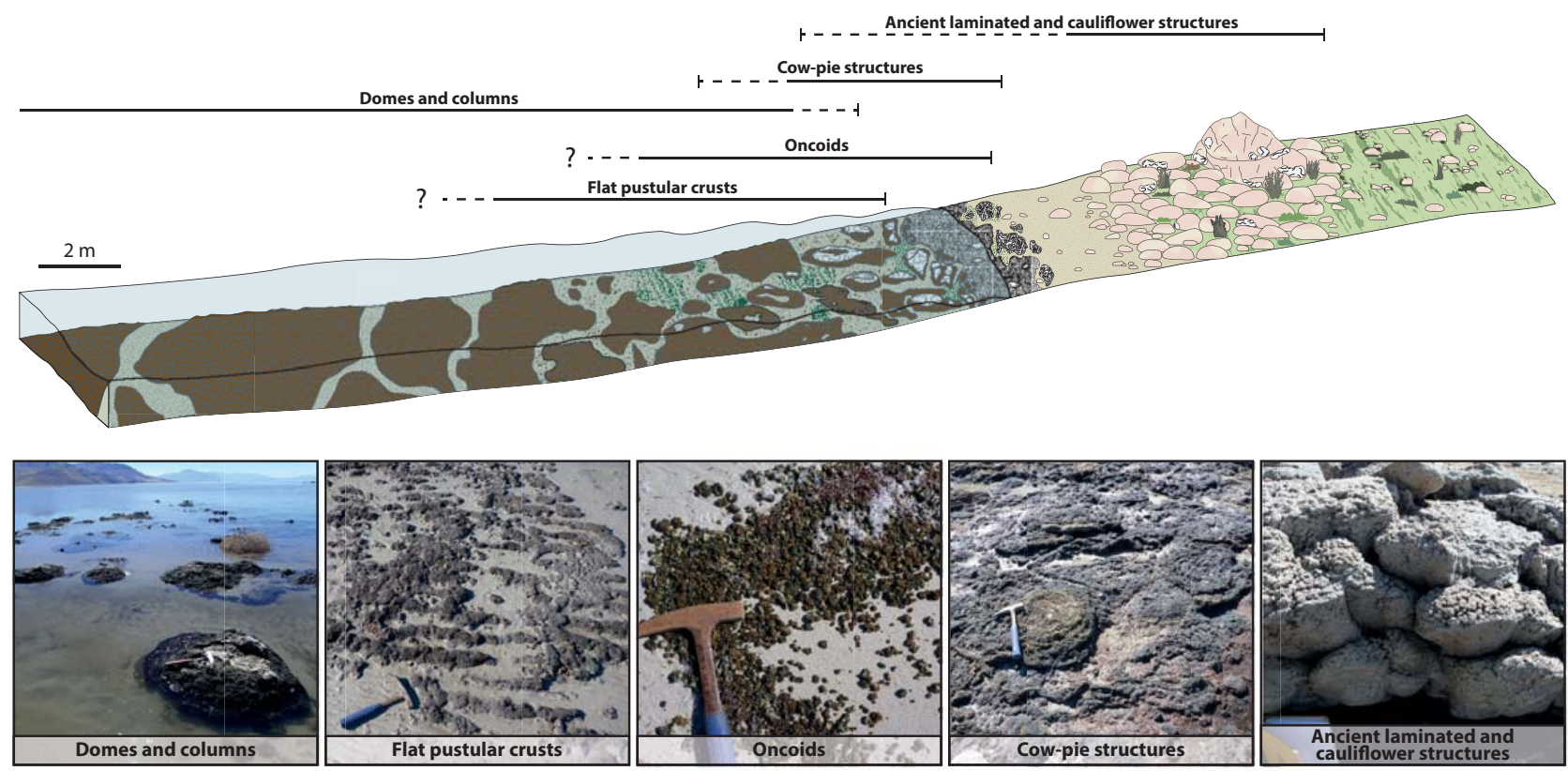

Figure 2. Shore-to-lake transect depicting the position of the microbial macrofabrics used for mapping.

spaces; Della Porta, 2015; Pace et al., 2016), are common, but there is a lack of living microbial mats. In the submersed area, microbially mediated precipitation (Dupraz et al., 2009) yields abundant microbialites (Fig. 3c, d) composed of carbonate minerals (aragonite evolving to dolomite) and preserved Mg clays through microbially mediated and early diagenetic processes (Pace et al., 2016). Microbially mediated precipitation goes along with trapping and binding processes which also participate in the accretion of these microbialites (Burne and Moore, 1987), covered by living microbial mats. The mats show a succession of thin orange and thick porous green clotted laminae.

The fossil microbialites correspond to laminated and cauliflower structures (Fig. 2), with early phases dated to ca. $21.9 \mathrm{kaBP}$ (Table 1). The laminated and cauliflower structures (15 and $30 \mathrm{~cm}$ high) are subdivided into four growing phases: (1) a first phase of coalescent lumps, 1 to $2 \mathrm{~cm}$ thick, showing successive clotted-thrombolitic and millimetre-sized laminated microstructures; (2) a second, 4$5 \mathrm{~cm}$ thick thrombolitic layer composed of peloidal and clotted clusters; (3) a third phase, consisting of 1-2 cm thick homogeneous laminae organized in a dense set of millimetresized micro-columns; and (4) a fourth phase, consisting of 5$15 \mathrm{~cm}$ thick bushy structures composed of highly recrystallized vertical loosely clotted columns. The last bushy structures fused, creating the cauliflower appearance (Fig. 3e). All the phases extend laterally in a covering drape of Cambrian quartzite and blocks of cemented microconglomerates (Fig. 3b).

In the temporarily exposed zone of the shore, cow-pie structures prevail as individual and coalescent structures
Table 1. Radiocarbon ages acquired for this paper.

\begin{tabular}{lrrl}
\hline Lab. number & 14C age BP & 14C error & Material \\
\hline POZ-77888 & 21900 & \pm 120 & Laminated and cauliflower \\
YAUT-016612 & 10634 & \pm 54 & Cow pie \\
YAUT-016613 & 7312 & \pm 113 & Cow pie \\
YAUT-016611 & 7060 & \pm 40 & Cow pie \\
POZ-77886 & 5780 & \pm 40 & Cow pie \\
YAUT-016617 & 3283 & \pm 42 & Ooid \\
YAUT-016620 & 2678 & \pm 72 & Domes and columns \\
YAUT-016619 & 64 & \pm 96 & Flat pustular crusts \\
YAUT-016618 & -11 & \pm 46 & Oncoid \\
\hline
\end{tabular}

(Fig. 2), with early phases dated to ca. $10.6 \mathrm{kaBP}$ and up to the present for living ones (Table 1). They are composed of microbialites, made of alternating laminated and clotted mesofabrics, covered by an active surface microbial mat when located below or slightly above the water surface. Semi-lithified to non-lithified cow-pie structures form an extended flat of coalescing structures with thicknesses comprised between 2 to $30 \mathrm{~cm}$. Each structure is limited to a few decimetres' to metres' width, while coalescent structures colonizing the flat reach tens or hundreds of metres; (Fig. 3a). When coalescent, the merging structures form a linearly growing upward ridge. The central part of cow pie can be frequently truncated in the exposed area with an erosion surface locally covered by a new cow-pie growing phase. The active microbial mat is also observed laterally as a flat pustular crust covering ooid sand ridges and sands as well as microconglomerates (Fig. 2). The associated mineralized microbially mediated carbonates are dated to ca. $0.064 \mathrm{kaBP}$ (Table 1). Oncoid sands, resulting from 

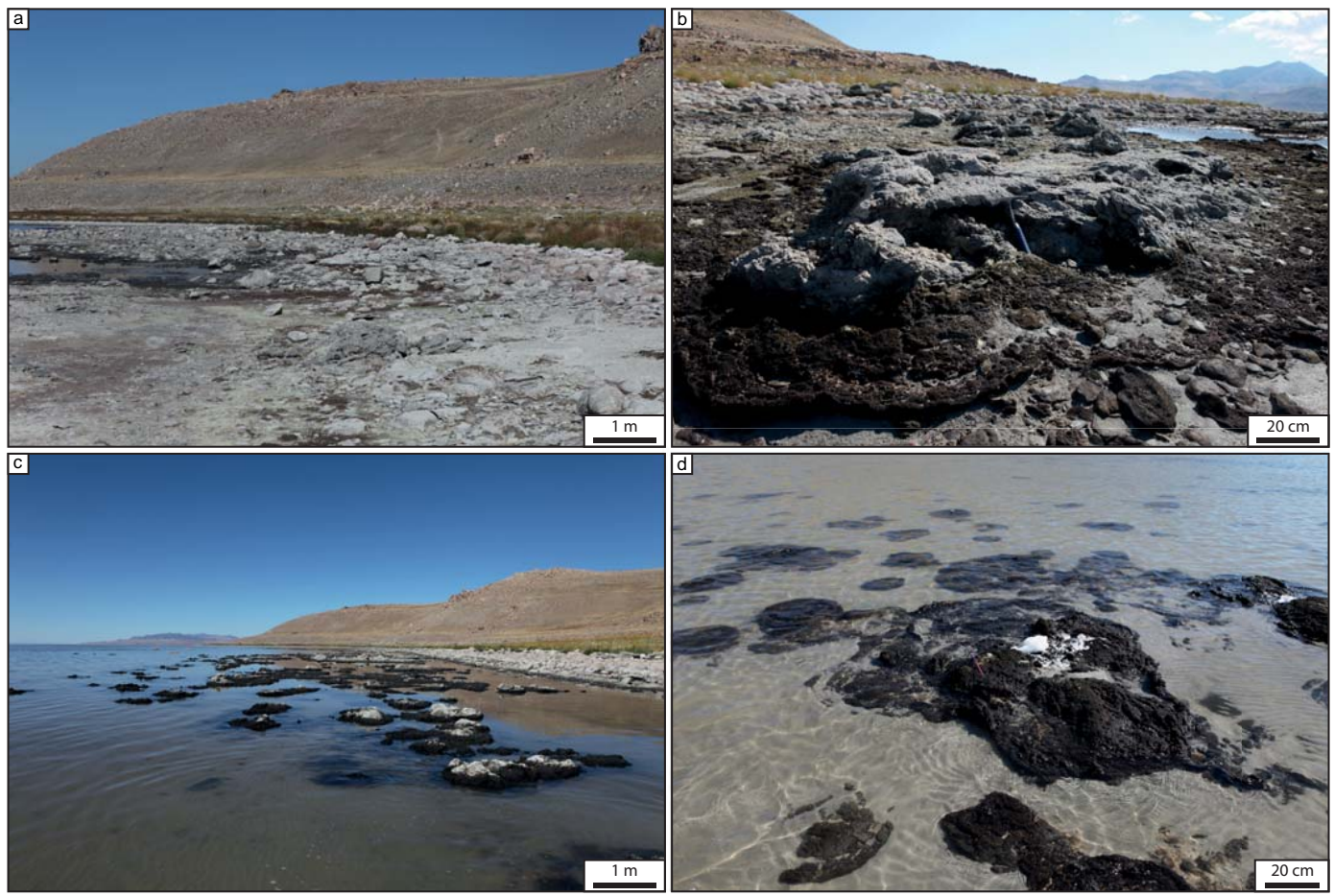

Figure 3. Panoramic view of the depositional environments on the shore. The microbial deposits are fossilized; the non-microbial deposits are dominated by Cambrian quartzite rounded blocks, quaternary microconglomerates and some ooid sands. (b) Details of the microbial deposits located in the area subject to annual water level fluctuations along the shore ( 2013 shown). The boundary between the living mat and the fossil part of the microbial structure indicates the water level elevation. (c) Panoramic view of the lakeward depositional environment. Most of the microbial deposits (cow-pie structures) consist of a living part (dark brown); the light grey appearance in microbial deposit surface is due to only mineralized structures, suggesting a prolonged period of emersion. (d) Details of the lakeward microbial deposits and the surrounding ooid sand.

the snatching of microbial mats, are observed accumulated along the shoreline (Fig. 2) and are considered recent sediment (ca. $-0.011 \mathrm{ka} \mathrm{BP}$; Table 1). They show a clotted mesofabric similar to the one observed in the living mats.

In a deeper environment, domes and columns (Fig. 2) present circular cross sections $(0.2-1.2 \mathrm{~m}$ in diameter; Della Porta, 2015; this study). The top of one of them, below the active microbial mat, has been dated to ca. $2.7 \mathrm{ka} \mathrm{BP}$ (Table 1). Temporarily exposed structures show deposition relief of less than $15 \mathrm{~cm}$ but reach a relief of several decimetres lakeward in deeper environments (1-2 m; Wurtsbaugh, W., personal communication, 2013). Their mesofabric is mainly clotted, with rare alternating laminated layers.

\subsection{Non-microbial deposits}

The non-microbial deposits present along the Antelope Island western margin are organized in a shore-to-lake transect. The shore flat deposits are dominated by subangular to rounded boulders composed of Cambrian quartzite in the NW part of the island. At the $1280 \mathrm{~m}$ a.s.l. shoreline, the pluri-decimetric to metre-sized rounded boulders are aligned in a conglomeratic belt (Fig. 3a). This shoreline marks the distal boundary of the boulder-dominated area. The shore domain also locally exhibits metre- to pluri-metre-sized tilted blocks of microconglomerates (Fig. 3b). These deposits are composed of angular quartz grains, forming a micro-breccia. The grain sizes range from $<1 \mathrm{~mm}$ to more than $2 \mathrm{~cm}$ and are organized in planar beds of fairly well sorted grains. The cementation is ensured by a fibrous aragonitic cement. Both boulders and microconglomeratic blocks are encrusted by the fossil laminated and cauliflower structures. Below $1280 \mathrm{~m}$ a.s.l., ooid sands are prevalent along the Antelope Island western margin (Fig. 3d). These sands are mainly composed of individual ooids associated with fecal pellets of Artemia and clastic grains as secondary components. The ooid sands can be classified as medium sands since the diameter of the ooids mostly ranges between 200 and $500 \mu \mathrm{m}$. The ooids show alternating radial and concentric layers of aragonite forming the cortices. A bulk radiocarbon dating on the cortex indicates an age of $3.3 \mathrm{kaBP}$ (Table 1). The nuclei are mostly made of fecal pellets or quartz fragments, even though some ooids have grown over ancient ooids or microbialite fragments. These sands are locally cemented, forming grainstones. The thickness of ooid sands is highly variable. In the shore flat, ancient ooid sands are preserved 
as $50 \mathrm{~cm}$ thick and $2-4 \mathrm{~m}$ large ridges parallel to the shoreline. In the temporarily exposed part of the shore, ooid sand thickness evolves from a few centimetres near the $1280 \mathrm{~m}$ shoreline to more than $70 \mathrm{~cm}$ in the ooid sand embayment of White Rock Bay (Fig. 1b). Towards deeper areas, the ooid sands overlie a finely laminated green to grey clay sediment, mostly composed of quartz, smectite, illite and ca. $30 \%$ of carbonates (dolomite and calcite). In the exposed embayments, these clays were also observed in surface as $10-30 \mathrm{~cm}$ wide strips showing a $5 \mathrm{~cm}$ relief above the flat. These strips form a polygonal network extending over hundreds of metres, individual polygons ranging from 5 to $20 \mathrm{~m}$ in diameter (Fig. 4a, b). In section, clay sediments exhibit a wedgeshape morphology widening toward the surface associated with gypsum crystals (Fig. 4c). Thin crusts of microbial mats can also be observed on the surface of the clay strips (Fig. 4d). The microbial mats show green or red pigments (Fig. 4e, f) and evolve from a planar to hemispheroid uncemented fabric. Other evaporites were also observed such as $<1 \mathrm{~mm}$ crust of halite at the surface of the exposed ooid sands and ephemerals of mirabilite $\left(\mathrm{Na}_{2} \mathrm{SO}_{4} \cdot 10\left(\mathrm{H}_{2} \mathrm{O}\right)\right)$ crystals in small depressions of the flat, frequently adjacent to the polygons (Fig. 4g, h). The sediments in the deepest parts of the lake consist of clays with a high amount of carbonates, especially near Antelope Island where Eardley (1938) reported a ca. $70 \%$ carbonate content (aragonite and dolomite).

\section{Mapping of microbial and non-microbial deposits and sedimentary structures}

\subsection{Method}

Geological field mapping (GPS, facies, sampling, etc.) was performed during three field campaigns in June 2013, September 2013 and November 2015 on the northwestern shore of Antelope Island, extending from White Rock Bay up to Bridger Bay (Fig. 1). Field observations were combined with aerial and satellite images. Aerial images were obtained from Google Earth Pro 7.1.2 (from State of Utah, USDA Farm Service Agency and NASA; unknown remote sensors), the Utah Automated Geographic Reference Center (2014 NAIP $1 \mathrm{~m}$ four-band (RGB and infrared) orthophotography, used in three-band RGB natural colour), and the USGS EarthExplorer (aerial photo single frames, NAPP, NAHP; mixing black and white, RGB and infrared bands). Satellite images correspond to Digitalglobe ${ }^{\circledR}$ images (WV02 spacecraft, imaging bands Pan-MS1-MS2; obtained from Garmin Birdseye) and Landsat images (NASA Landsat Program, 1972 to 2015, L1-5 MSS/L4-5 TM/L7 ETM+ SLCOn/L7 ETM+ SLCOff/L8 OLI/TIRS, Sioux Falls, USGS, 08/07/72-10/13/2015). The dark orange to dark green pigments of the modern living mats in the aerial and satellite images allow us to distinguish between submersed living microbial deposits and light-coloured uncolonized ooid sands or clays. This mapping approach required suitable visibility through the atmosphere and water column, and images showing water turbidity, cloud cover or waves were discarded. Aerial images have been imported into ArcGIS in order to perform the mapping. The first approach consists in converting the pixel showing microbial deposits into black pixel and integrating them into a shapefile layer. The percentage of points (i.e. microbial deposits) per surface unit was used in order to calculate the density of the microbial structures (in ArcGIS; point density tool, $15 \mathrm{~m}$ output cells and $50 \mathrm{~m}$ circular neighbourhood). Calculations were difficult below a pixel resolution of $15 \mathrm{~m}$ due to the high amount of point; thereby it was completed with a visual approach improving the mapping resolution. For this we defined high- and low-density areas of microbial deposits in aerial images, which match with the perception in the field. These results have been placed on a metric topographic map for the GSL floor. This map was constructed by extrapolating the map (in feet) provided by Baskin and Allen (2005).

\subsection{Results}

The distribution of the microbial, non-microbial deposits and relevant sedimentary structures along Antelope Island is mapped in Figs. 5 (standard resolution maps and aerial images) and S1 (high-resolution distribution map) in the Supplement. It complements the maps published by Eardley (1938) and Baskin et al. (2012; based on geophysical data). Using recent aerial images of the Antelope Island area, we estimate that the coverage of the microbial deposits may be at least $90 \mathrm{~km}^{2}$ wide with a patchy distribution and a density varying from isolated to a local full coverage of the lake bottom (Fig. 5a, b). A comparison of the temporal series of aerial images (since 1950) provides insights into the migration and burying dynamics of the microbial deposits (Fig. 6a, b). For instance, on the western Antelope Island margin, microbial deposits appeared to be intermittently buried by loose sediments (Fig. 6a, b). This process likely results in a ca. $10 \%$ underestimation of the total surface of the western Antelope Island margin covered by microbial deposits. An initial approximation of $260 \mathrm{~km}^{2}$ has been proposed by Eardley (1938) for the extent of the microbial structures in the whole lake. Only considering the Antelope Island area, our mapping results reach a third of the total extent proposed by Eardley (1938). Therefore, its initial estimation is likely an underestimation as (i) a significant part of these structures can be buried under the ooid sand or clay sediments and (ii) they are partially eroded around the shoreline (Fig. 6).

Most microbial deposits around the margin of Antelope Island were found between $7.5 \mathrm{~m}$ below (1272.5 ma.s.1.) and $3 \mathrm{~m}$ above (1283 ma.s.l.; Fig. 5c) the MHWL. Above $1280 \mathrm{~m}$ a.s.l., microbial deposits are scattered and mainly correspond to fossil laminated and cauliflower structures. In the temporarily exposed zone of the shore facing steep topographic area, cow-pie structures are preserved along the 


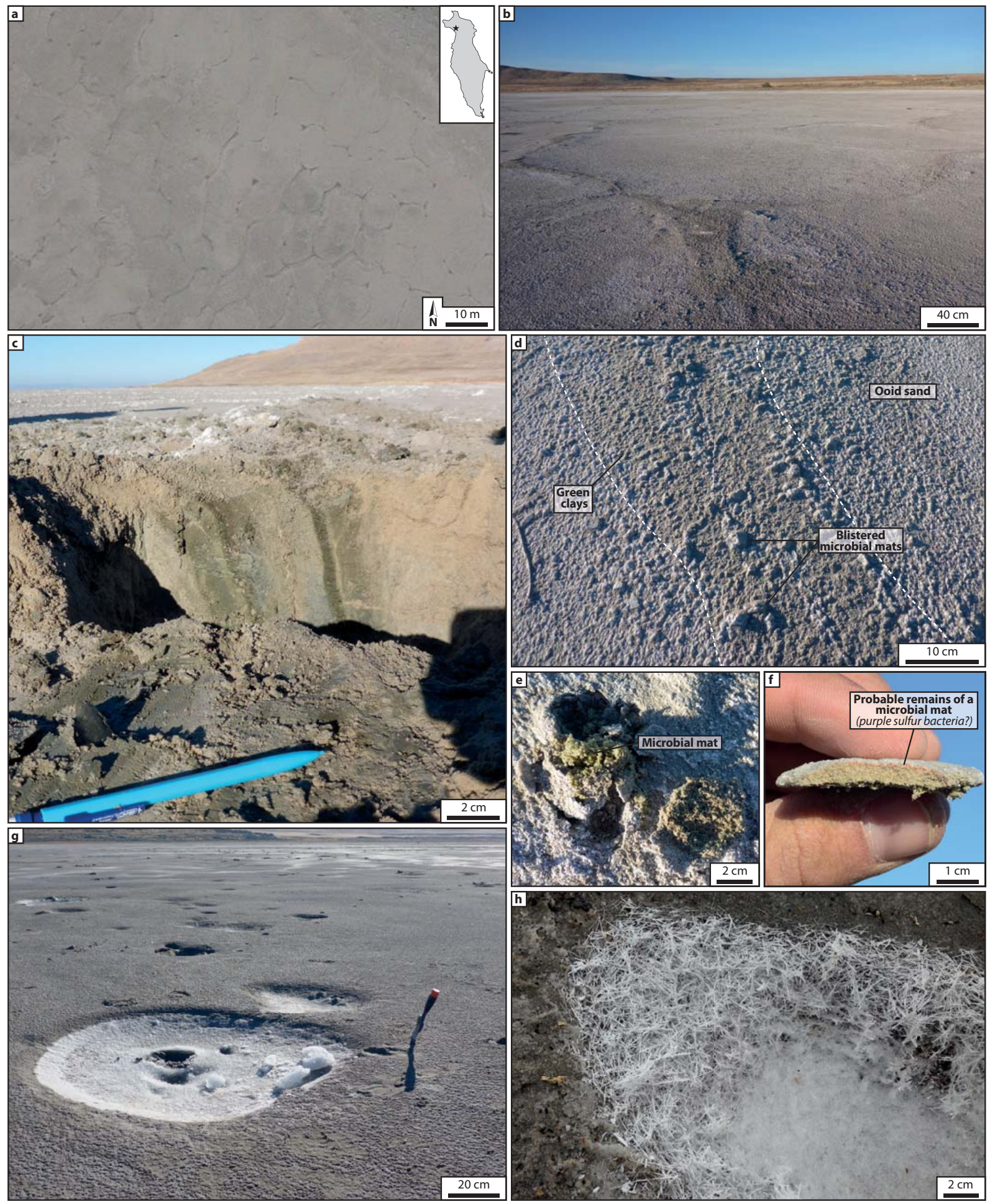

Figure 4. Polygonal architectures of the emersed White Rock Bay ooid sand flat. (a) Aerial image of the White Rock Bay polygons (Google Earth). (b) Field photograph of the emersed polygonal architecture observed in the sand flat with the rise of the underlying green clays in the cracks. (c) Section through the crack of a polygon showing the rise of the green clays. The different vertical shades of green suggest preferential fluid pathways through the clays. (d) Formation of microbial mat hemispheroids through blistering above the polygons. (e) Cut into a microbial mat hemispheroid showing green pigments, which are frequently associated with cyanobacteria. (f) Section within a hemispheroid made of cemented ooid grainstone. The presence of an infra-millimetre thin red-coloured layer $0.5 \mathrm{~mm}$ below the top probably reflects the presence of purple sulfur bacteria. (g) Accumulations of mirabilite $\left(\mathrm{Na}_{2} \mathrm{SO}_{4} \cdot 10\left(\mathrm{H}_{2} \mathrm{O}\right)\right.$ ) within small depressions (sinkholes) in the vicinity of the polygons. (h) Detail of mirabilite crystals. 


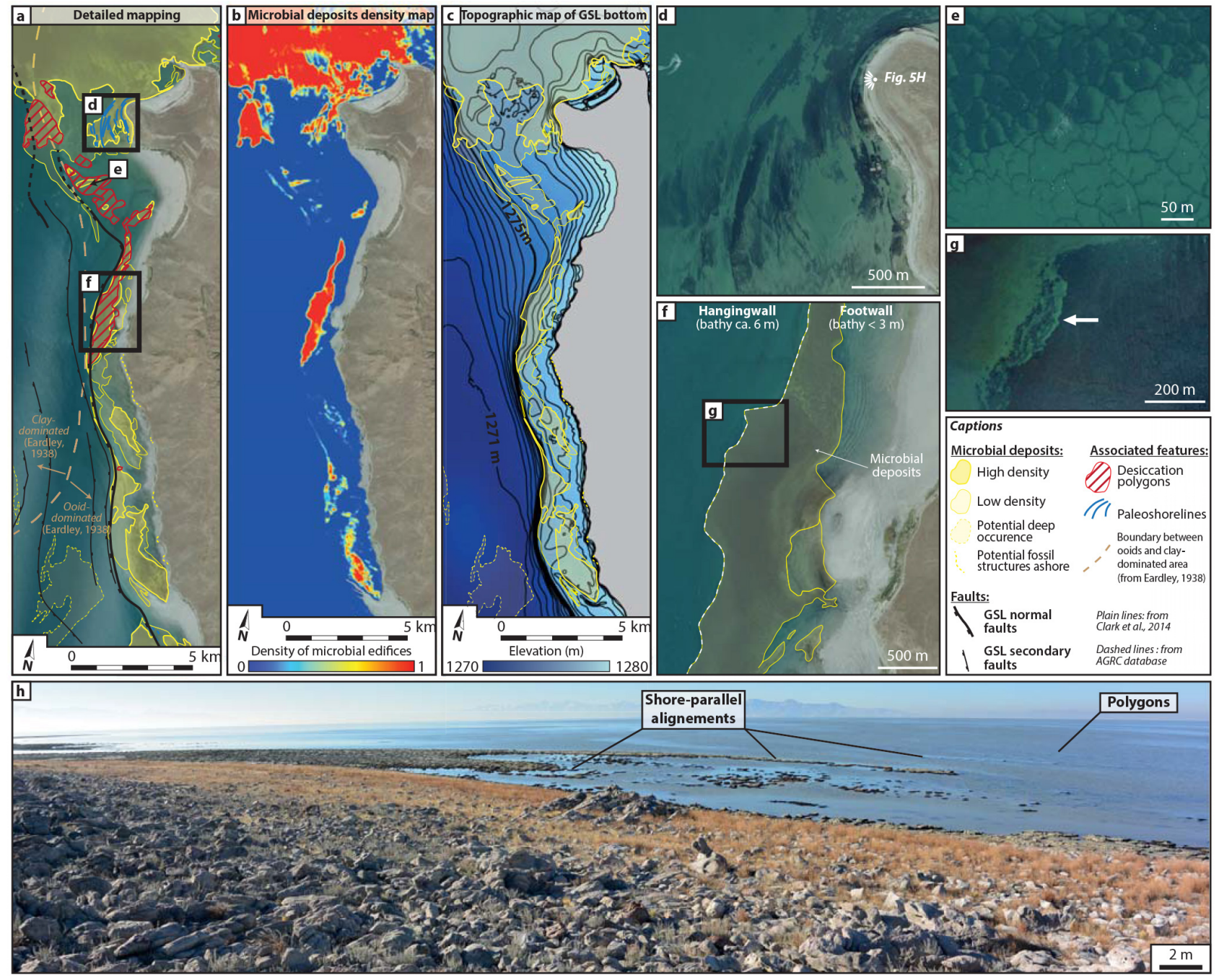

Figure 5. Detailed maps of the western side of Antelope Island. (a) Distribution and organization of the microbial deposits and sedimentary structures (2014 NAIP 1 m orthophotography). (b) Density map of the distribution of the microbial deposits. (c) Bathymetric map showing isopleths of $0.5 \mathrm{~m}$. (d) Details of the microbial alignments interpreted as paleoshorelines. (e) Details of the desiccation polygons. (f) GSL major normal fault and lower limit of the microbial deposits (white dashed line); the microbial deposits are present in the footwall (yellow polygon) but not observed on the hanging wall. (g) Details of a lens-shaped detachment of the microbial deposits resulting from gliding (white arrow). (h) Photographs taken from the heights of the NW area of Antelope Island of the shore-parallel alignments of the microbial deposits on the shore.

flat. They are absent in the embayment areas (like White Rock and Bridger bays; Fig. 1) in front of low topographic areas. They form a dense network just below $1280 \mathrm{~m}$ a.s.l., showing a scattered to full-coverage distribution. In addition, the cow-pie macrofabrics are located along linear belts following isobaths and are locally observed in a relative paleohigh induced by the presence of unusual conglomeratic deposits (Fig. 5h). Lakeward, cow-pie structures give way to domes and columns, which are organized as isolated circular structures or coalesce, merging into clusters. Between $1276 \mathrm{~m}$ and $1278.5 \mathrm{~m}$ a.s.l. (4 and $1.5 \mathrm{~m}$ below the MHWL), microbial structures are frequently arranged in metre- to kilometre-long linear belts following the isobaths and are parallel to the shoreline (Fig. 5a, d). They are also organized following the edge of $20-80 \mathrm{~m}$ wide submersed polygons (Fig. 5a, e, h). Locally, the centre of the polygons can be colonized as well. The polygons are interconnected in a network covering a surface of tens of square kilometres down to $1274 \mathrm{~m}$ a.s.l. Deeper occurrences of microbialites were reported (e.g. Colman et al., 2002); they are visible on aerial/satellite images when the conditions (e.g. turbidity) are optimal (Fig. 5a, dashed yellow polygons; ca. $9 \mathrm{~m}$ below the MHWL, $1271 \mathrm{~m}$ a.s.l.). The depth limit of the microbial deposits along the western margin of Antelope Island (approximately $5 \mathrm{~m}$ ) coincided with a relatively sharp topographic drop-off (Fig. 5a, c, f). This abrupt slope break marks the 


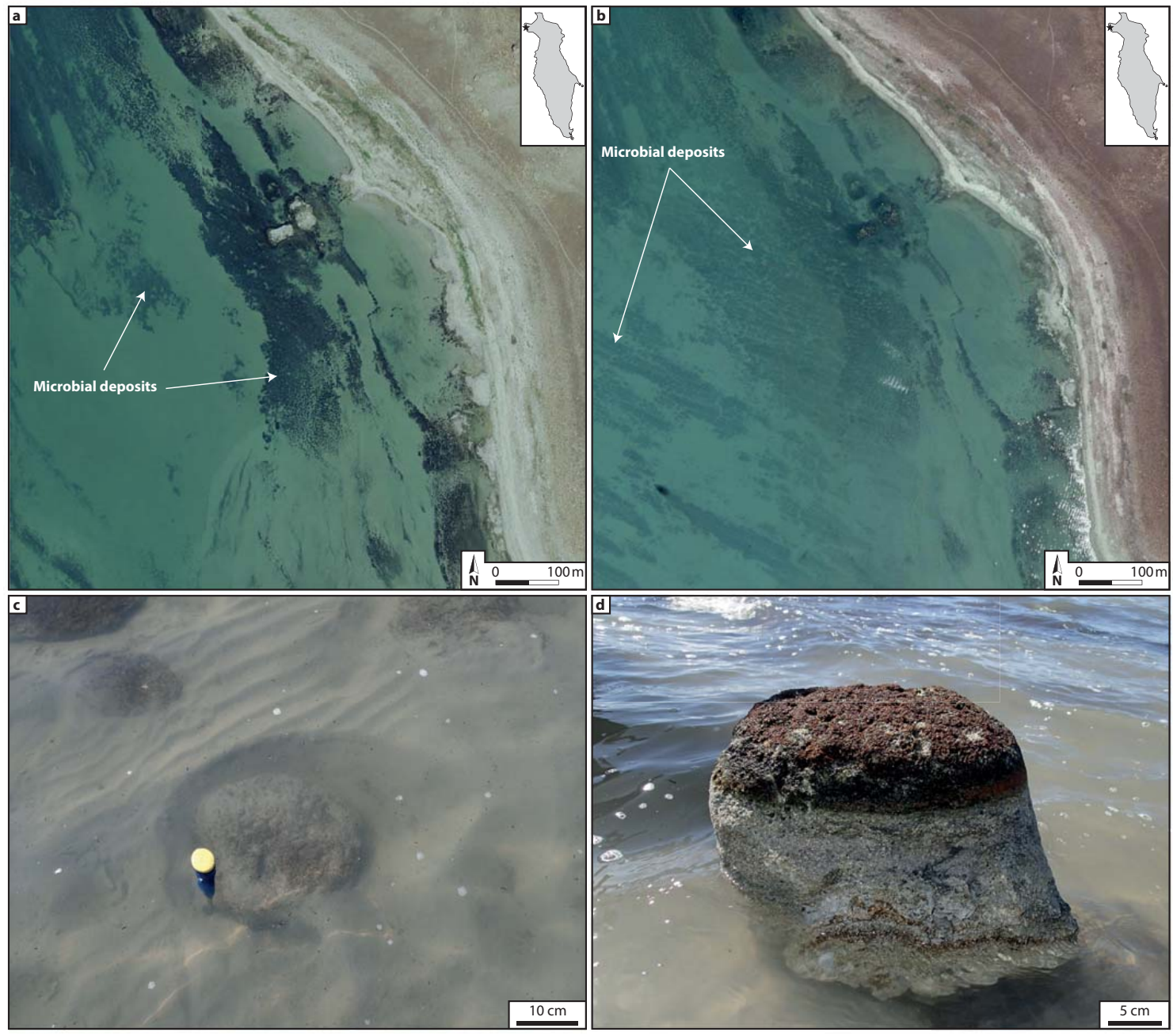

Figure 6. Illustrations of sediment removal. (a) Typical aerial/satellite images of NW Antelope Island (since 1950) with abundant microbial deposits (2014 NAIP $1 \mathrm{~m}$ orthophotography). (b) The same area as shown in panel a showing the burial of microbial deposits in ooid sands (Digitalglobe®images through the Garmin Birdseye software; exact date unknown but probably ca. 2013). Panels (c) and (d) depict a microbial structure that is partially buried in the ooid sand; the outcropping part (c; $3 \mathrm{~cm}$ high) is the only visible part; after removal from the surrounding sediment, the structure is $40 \mathrm{~cm}$ high (d), and the base of the column shows the attachment to an indurated substrate.

transition from a shallow platform shoreward with abundant microbial deposits to a deeper area with rare occurrences of microbialite (Fig. 5a, c). Along the slope break, scattered lens-shaped detachments of microbial structures have been observed (Fig. 5g).

\section{Role of climatically induced water level fluctuations on microbial deposit distribution}

\subsection{Markers of lake level fluctuations}

\subsubsection{Present-day water level}

Living microbial mats develop on top of microbialites (cow pie and domes and columns) and cemented ooid sands documented in the submersed area. They can also persist on the shore where emersion is limited to a short time, e.g. corresponding to annual water level fluctuations. Therefore, the upper occurrence of the living mat, corresponding to the boundary between living and ancient structures, is a good indicator of the annual mean elevation of the shoreline.

Onshore, the polygonal networks are associated with green clays and prismatic gypsum crystals, thin crusts of microbial mats resulting from blistering and mirabilite mineral, reflecting alternating wet/dry conditions. Such conditions are suitable for the formation of desiccation polygons (Warren, 2006). The extended polygonal networks observed in the embayments area are indeed related to desiccation processes. The polygons are locally encrusted by microbial mats probably associated with fluid circulations in the underlying crack system (Bouton et al., 2016). Both the sedimentary structures and the evaporite can be used to define the emersion condi- 
tions and to estimate the shoreline position. Based on a uniformitarianism approach, we therefore consider that similar structures with the same underlying processes are preserved in the fossil record.

\subsubsection{Past lake levels}

The occurrence of ca. $21.6 \mathrm{ka}$ BP laminated and cauliflower microbialites, up to $3 \mathrm{~m}$ above the MHWL, indicates that the lake level was (i) much higher when these structures developed and (ii) lasted long enough to support mineral precipitation and growth. The growth rates reported in the literature are generally below $1 \mathrm{~mm} \mathrm{yr}^{-1}$ (e.g. between 0.1 and $0.54 \mathrm{~mm} \mathrm{yr}^{-1}$ for the Shark Bay microbialites and potentially up to $0.75 \mathrm{~mm} \mathrm{yr}^{-1}$; Jahnert and Collins, 2012; ca. $0.16 \mathrm{~mm} \mathrm{yr}^{-1}$ in a Bahamian lagoon, with a maximal growth rate estimated at $0.88 \mathrm{~mm} \mathrm{yr}^{-1}$; Paull et al., 1992; and ca. $0.1 \mathrm{~mm} \mathrm{yr}^{-1}$ for the hypersaline dolomite stromatolites of Lagoa Salgada, Brazil; Bahniuk Rumbelsperger, 2013). Some of the laminated and cauliflower structures on the shore of the GSL are $>30 \mathrm{~cm}$ high. Continuous intervals of up to $15 \mathrm{~cm}$ and the absence of major discontinuities suggest no long-term exposures during microbial deposit growth. Considering a growth rate of $0.88 \mathrm{~mm} \mathrm{yr}^{-1}$ and $15 \mathrm{~cm}$ of continuous growth, the formation of these structures would have required at least 170 years.

The Fig. 5 shows the distribution of the microbial deposits and associated features (faults, dominant sediment, GSL bottom topography, etc.) along the western Antelope Island shoreline. Along a shore-to-lake transect, microbialites are frequently observed aligned and following polygons. Most of the cow-pie structures are aligned along the major $1280 \mathrm{~m}$ shoreline. They are observed on the surface of proximal domes and columns alignments, alignments which persist down to $1276 \mathrm{~m}$ a.s.l.. Considering their similarity with the present-day shoreline, the metre- to kilometre-long linear arrangements of microbial structures following the isobaths and parallel to the shoreline are interpreted as paleoshorelines. The microbialites track approximate shorelines, as they must form in (at least predominantly) submerged environments. Each alignment represents a specific water elevation during periods of stable lower water levels. The development of the cow-pie structures along the shoreline may constitute an initial step in the formation of larger structures, resulting in submersed alignments.

In the submersed area (between 1278.5 and $1274 \mathrm{~m}$ a.s.l.), microbial deposits are also closely associated with a polygonal network where they develop following the edges and occasionally colonize the centre of these polygons. The same polygonal geometry associated with microbial mats interpreted as desiccation structures have been observed in the emersed embayment area. Therefore, the submersed polygons are considered remnants of desiccation polygons related to past stable low water levels of the GSL. The regular pattern of polygons and their morphology are indicative of desiccation rather than synaeresis formed under subaqueous conditions (Nichols, 2009). This extensive polygon development requires a protracted and high-amplitude drop in the lake water level. Their presence and stability shown by old USGS aerial images indicate that they formed prior to 1950 and that they have been stable since then. These polygonal networks were previously documented by Currey (1980), but they were not linked to any type of microbial structures. They are similar to the polygonal structures identified in Great Basin playas (Neal et al., 1968). Currey (1980) interpreted the GSL polygons as a giant desiccation crack network which may have formed in aerial conditions by the drying out of a sediment that was previously waterlogged (Nichols, 2009). Giant desiccation polygons have been recognized in the recent shore domain of White Rock Bay (this study; Fig. 5a, d). The present-day polygon position down to $1274 \mathrm{~m}$ a.s.l. ( $6 \mathrm{~m}$ below the MHWL) implies a low water elevation during their formation. The submersion of polygons following a flooding may trigger the preferential development of microbial structures at the edges of the polygons, i.e. atop the cracks, and then favour the preservation of the polygons. This process can be enhanced by preferential fluid migration through cracks and underlying fractures (Fig. 5c, f; Bouton et al., 2016), which may provide an important source of ions (e.g. $\mathrm{Ca}^{2+}$ ) favouring microbial mat growth and/or mineralization. We hypothesize here that the formation of the desiccation polygons occurs during emersion but that the establishment of mineralizing microbial deposits associated with the polygons allows the preservation of this peculiar sedimentary geometry through time (Gerdes, 2007; Bouton et al., 2016).

\subsection{Climate as a major driver of microbial deposit distribution}

The previous results suggest that microbial and sedimentary structures accurately record water level fluctuations. The lake water volume increases in spring and early summer owing to snowmelt and rainfall and decreases in late summer and autumn due to extensive evaporation. Analyses of aerial images spanning the last 7 decades, combined with our field observations, suggest a rather stable development and position of the observed microbial structures (at least 170 years for a $15 \mathrm{~cm}$ thick structure and 22 years for a $2 \mathrm{~cm}$ thick crust, assuming a growth rate of $0.88 \mathrm{~mm} \mathrm{yr}^{-1}$ ). Annual and shortterm (i.e. a few years) fluctuations in the GSL water level cannot account for their development given that the inundation episodes are not long enough, even if the GSL water level fluctuation has reached an amplitude of $7 \mathrm{~m}$ since 1963. The origin of the microbial deposits, especially the ancient structures above the MHWL, paleoshorelines and polygonal networks, can be related to older and longer water level fluctuations. The peculiar distribution of the microbial deposits and their duration are therefore used in the following discussion to suggest a chronological succession of the lake level 
variations. The lake level has strongly varied since its formation ca. $30 \mathrm{kaBP}$, and its variations are shown in Fig. 7, which combines three different reconstructions taken from the literature (McKenzie and Eberli, 1985; Murchison, 1989; Patrickson, 2010). The first one is proposed by Patrickson et al. (2010) and encompasses the whole LB history. This curve presents a low-resolution pattern for the LB water level variations based on a compilation of radiocarbon ages. The second reconstruction corresponds to a synthetic curve obtained by Murchison (1989) compiled from numerous works combining different approaches (e.g. sedimentology, geomorphology, archaeology, palynology and stable isotopes) (e.g. Ross, 1973; Rudy, 1973; Currey, 1980; Currey and James, 1982; Currey et al., 1984; McKenzie and Eberli, 1985). This curve spans the period from the present to the late LB phase and has been calibrated with radiocarbon dating on various materials (e.g. woods, charcoals, marsh). However, Murchison's curve (1989) reflects specific events, whereas continuous and detailed records are mandatory here. The third reconstruction is from McKenzie and Eberli (1985), who reconstructed the last 5500 years using the $\delta^{18} \mathrm{O}$ isotope signal from the bulk carbonate content of a sedimentary core obtained near Antelope Island. It shows an apparent correlation between the oxygen-isotope record of the upper $20 \mathrm{~cm}$ of the studied core and the direct measurement of the historic GSL water level fluctuations since 1876. The $\delta^{18} \mathrm{O}$ fractionation associated with lake elevations yields an average rate of approximately $0.35 \% \mathrm{om}^{-1}$. This approach provides a high temporal resolution with, on average, one extrapolated value of the lake level every 88 years. However, their sampling resolution (ca. $0.5 \mathrm{~cm}$ ) corresponds to a time average of ca. 20 years and hence tends to smooth the signal, including several specific events.

According to the reconstructions of McKenzie and Eberli (1985), Murchison (1989) and Patrickson (2010), only the initial history of LB or the last ca. $11.5 \mathrm{kyr}$ phase correspond to a period of low water level around $1280 \mathrm{~m}$ a.s.l. (Spencer et al., 1984) and may be involved in the formation of the extended microbial deposits described above. The presence of well-dated microbial deposits on the four main LB terraces indicates that they formed during the whole lake history. However the geomorphology of the successive LB terraces, characterized by a reduced extension of the shore, is conducive to a restricted spatial extension of the associated microbial deposits.

The role of climate in the GSL level fluctuations was recognized both in its recent history (e.g. Lall and Mann, 1995) and during the LB phase. For instance, Godsey et al. (2005) suggested that very dry conditions resulted in the drastic water level decrease (ca. $160 \mathrm{~m}$ ) following the Provo stage (ca. 12 ka BP; Fig. 7). McKenzie and Eberli (1985) proposed a climatic control on the GSL level fluctuations. They discussed cyclic fluctuations over the past 5500 years (Fig. 7) and estimated an amplitude for the water level fluctuations of ca. $6 \mathrm{~m}$, (i.e. between 1278 and $1284 \mathrm{~m}$ a.s.l.), showing a 1500-year duration for the maxima and a 750-year duration for the minima. Similarly, Murchison (1989) proposed several long-term water level increases and decreases (Fig. 7). Our results suggest that the distribution of the microbial deposits and sedimentary structures (e.g. alignments, polygons) is related to fluctuations in the lake level and consequently mostly to climatic changes. The local influence of tectonics (Holocene fault activity) cannot be excluded but cannot be related to the post-Bonneville isostatic rebound, which is considered negligible during this period (Oviatt, 2015).

Here we propose to discriminate the different major climatic events involved in the non-random distribution of microbial deposits (Fig. 7) using a composite LB curve provided by Patrickson et al. (2010), McKenzie and Eberli (1985) and Murchison (1989). A water elevation of $1283 \mathrm{~m}$ a.s.l. is necessary to explain the presence of the laminated and cauliflower structures $3 \mathrm{~m}$ above the MHWL (Fig. 7) dated to ca. $21.9 \mathrm{ka} \mathrm{BP}$. At anytime, during the GSL phase, water level elevations exceeding $1283 \mathrm{~m}$ a.s.l. were probably too brief to allow the growth of microbialites. Considering the higher growth rate suggested in this work $(15 \mathrm{~cm}$ phase growing over 170 years at $0.88 \mathrm{~mm} \mathrm{yr}^{-1}$ ), only intervals of more than 150 years might be considered. The unique candidate issuing from the low-resolution Murchison curve is an interval between ca. 3.5 to $1.3 \mathrm{ka} \mathrm{BP}$. While the higher resolution curve proposed by McKenzie and Eberli (1985) confirms this high water level episode, its duration is reduced down to 250 years. Although this time interval is sufficient at a maximal growth rate, the most commonly reported rates (ca. $0.5 \mathrm{~mm} \mathrm{yr}^{-1}$; e.g. Jahnert and Collins, 2012) do not allow the growth of this microbial structure in such a short time interval. Moreover, the $21.9 \mathrm{ka}$ BP radiocarbon age obtained for the laminated and cauliflower microbial structures rules out the hypothesis of a development during the GSL phase and rather supports a formation during the LB phase and potentially during the Stansbury oscillation (22.0 to $20.0 \mathrm{ka}$ BP; Patrickson et al., 2010). Observed structures, moreover, rather resemble the ones developed on Stansbury and Provo terraces (21.0 and 15.5-12.5 ka BP, respectively; Oviatt, 2015) than the ones developed during the GSL phase. However, this novel age is puzzling regarding the published curves of LB water level reconstruction (e.g. Oviatt et al., 1992; Patrickson et al., 2010; Oviatt, 2015). Indeed, the estimation of the lake water level was $50 \mathrm{~m}$ higher at this period than the proposed low water level associated with the development of such structures. Their presence in the deeper part of the Bonneville Basin, close to the modern GSL configuration may therefore underline two phenomena: (i) a previously unrecognized low water level occurrence during the Stansbury oscillation (22.0 to $20.0 \mathrm{ka} \mathrm{BP}$; Patrickson et al., 2010) or (ii) a reset of the radiochronometer at this period, suggesting that these deposits formed earlier in the lake history, when the lake level was at its lowstand configuration such as the early LB phase. New analyses and dating are 

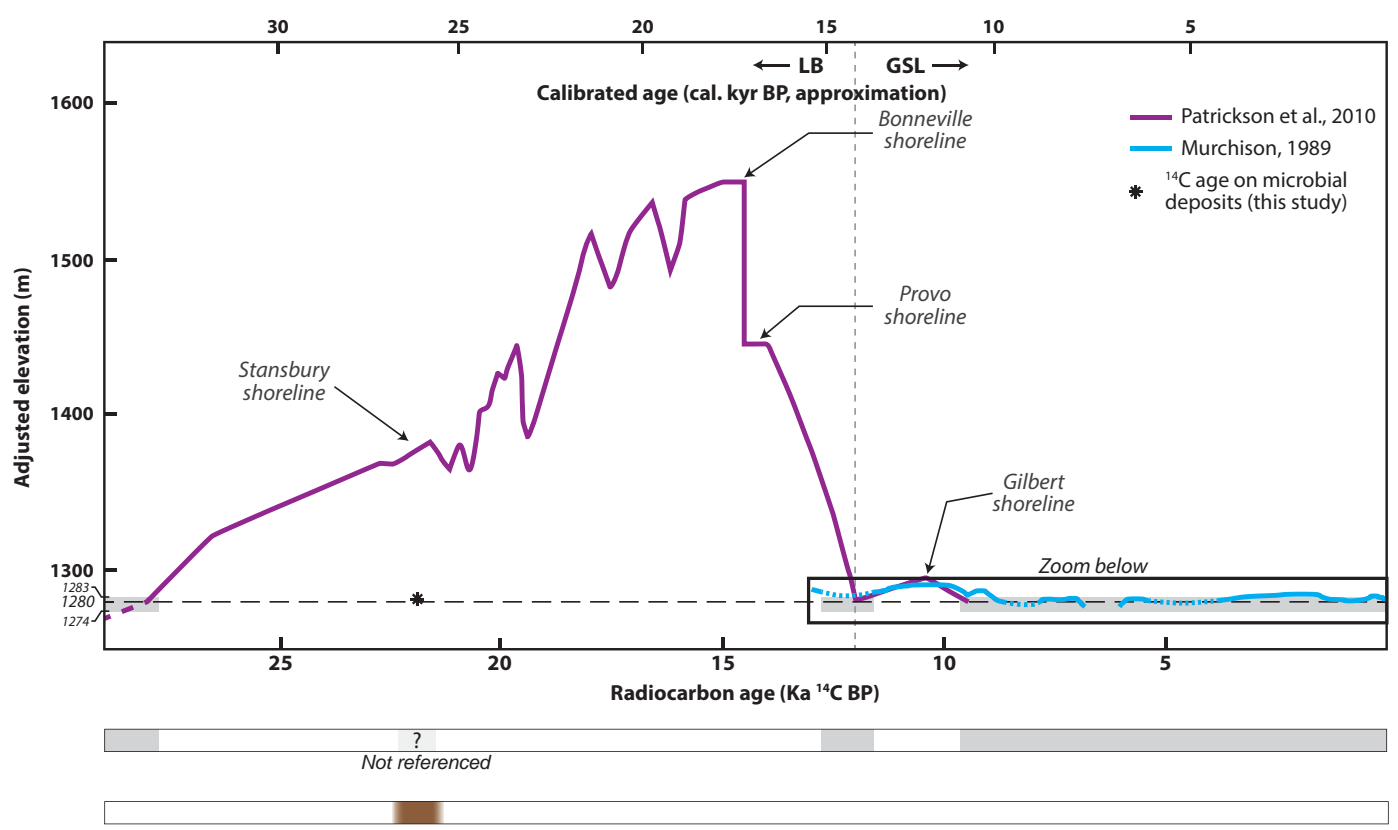

Potential periods of develope ment of the microbia structures located around or below the 1280 m elevation

Laminated and cauliflower structures

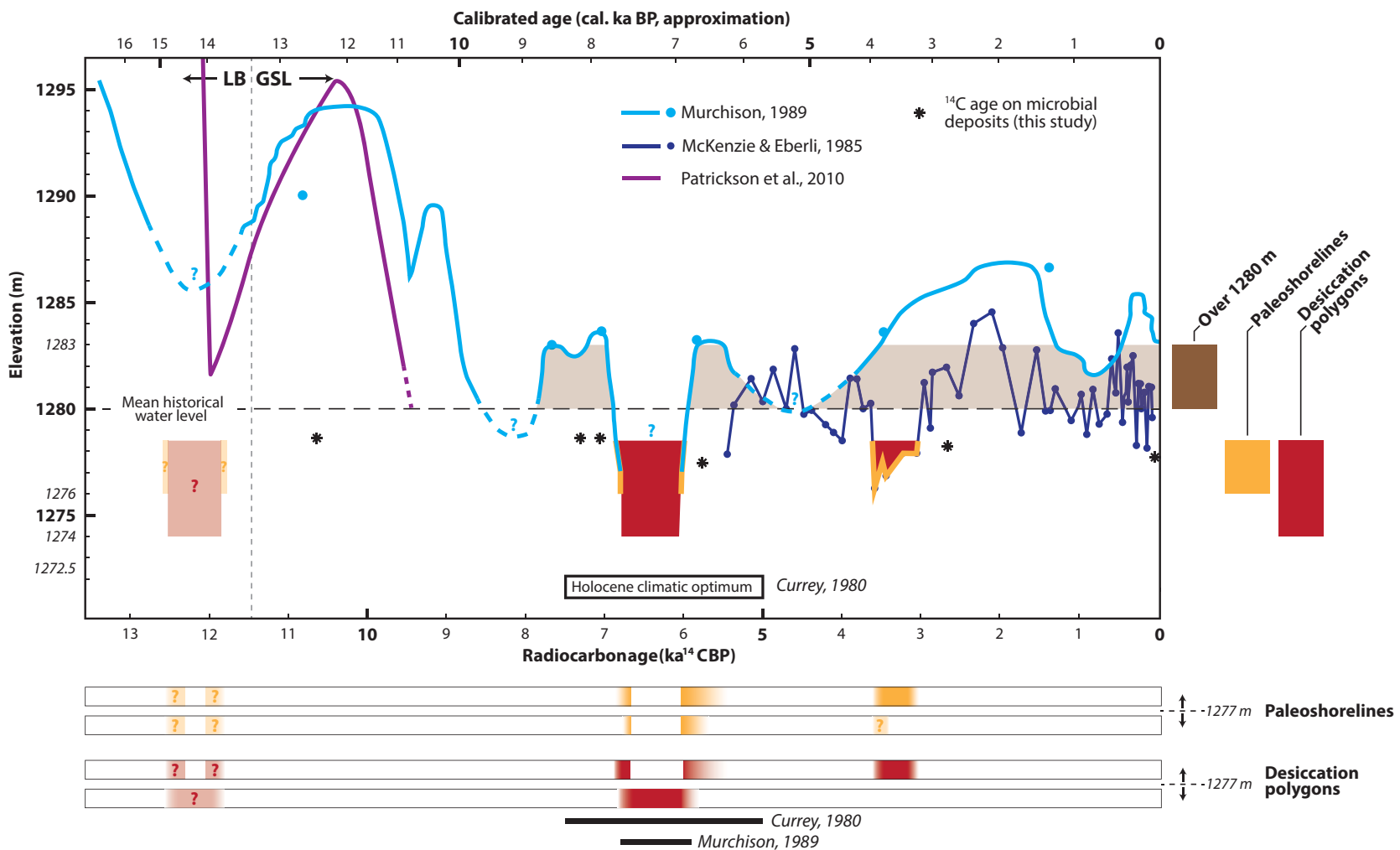

Figure 7. Reconstitution curve of the water level at Lake Bonneville and the Great Salt Lake showing potential periods of formation of the fossil microbial structures (brown), paleoshorelines (yellow) and desiccation polygons (red).

therefore mandatory to understand the depositional context of these enigmatic microbialites.

The development of microbial deposits near the shore or toward the lake may have taken place during the entire his- tory of the GSL and potentially during the late LB phases, because they could have formed near or below the mean range of the water level fluctuations. These deposits indicate a water level for the shoreline close to the modern one during this 
period. It fits with episodes above the MHWL recorded in Murchison's curve (1989). However, the presence of desiccation polygons and microbialite-rich shorelines at low elevations (1274 $\mathrm{m}$ a.s.1. for the deeper desiccation polygons and $1276 \mathrm{~m}$ a.s.l. for the deepest paleoshoreline) suggests the occurrence of very low lake levels, which are rare in the history of the GSL (Fig. 7). All of the paleoshorelines displaying from the modern shore to ca. $1276 \mathrm{~m}$ a.s.l. may have developed between ca. 3.6-2.9 ka BP (Fig. 7). The corresponding low level can explain the shallow polygons but is not low enough to explain the deepest ones (ca. $1274 \mathrm{~m}$ a.s.l.). The formation of deeper polygons and paleoshorelines could also have occurred during other major events of low water levels (Fig. 7). The first known event corresponds to the Holocene climatic optimum (ca. 7.5-5.0 ka BP; Currey, 1980), which resulted in a drastic water level drop for North American lakes (Street and Grove, 1979). During this period, the GSL level dropped to $1274 \mathrm{~m}$ a.s.l. (Murchison, 1989) and a large part of the GSL was an almost desiccated playa (Currey, 1980). Currey (1980) postulated that the desiccation polygons were formed during this period, and Murchison (1989) further narrowed down the dating for polygon development between ca. 6.9-6.0 ka BP (Fig 7). A low lake level during this period has also been suggested using a slight angle truncation in a seismic reflector that correlated with a $6.7 \mathrm{ka} \mathrm{BP}$ tephra (Colman et al., 2002). A significant amount of authigenic dolomite in the sediments in association with the playa configuration is also documented for this time interval (McKenzie and Eberli, 1985). Dolomite precipitation can result from chemical precipitation under evaporitic conditions (Pierre et al., 1984) but also from microbial organomineralization (Vasconcelos et al., 1995). A second and older episode of low water levels occurred at the end of the LB phase, ca. $11.5 \mathrm{kaBP}$ (Fig. 7). A drill core from the deepest part of the GSL $\left(41^{\circ} 07^{\prime} 50^{\prime \prime} \mathrm{N}-112^{\circ} 33^{\prime} 46^{\prime \prime} \mathrm{W}\right)$ showed the presence of thenardite layers between 14.4 and $8 \mathrm{~m}$ below the lake floor, with an intercalation of black sapropelic muds (Balch et al., 2005). The age of these layers was estimated between $17 \pm 3$ and $11 \pm 4$ cal ka (U series geochronology; can be approximated in uncalibrated radiocarbon age to 13.89.6 ka BP), and they probably relate to a low lake level succeeding the post-Provo regression and preceding the Gilbert transgressive episode. The deposition of a $6 \mathrm{~m}$ thick evaporitic layer in this part of the lake suggests an extensive desiccation event forming a playa environment with only few remaining salt marshes and/or hypersaline ponds. The lake level during this event was low enough to expose the whole microbialite-polygon area. The presence of an $8 \mathrm{~m}$ thick sedimentary record above the thenardite layer, ca. $25 \mathrm{~km}$ away from the NW Antelope Island, in one of the deepest parts of the GSL, suggests that extensive erosion removed the homogeneous sedimentary cover in the NW Antelope Island area. Accordingly, even if the accumulation of sediment was probably thinner near Antelope Island, given that it is a topographic high, the thickness of the sedimentary record is prob- ably still too large and will cover the polygons. Additionally, the homogeneity of the seismic reflectors acquired close to Antelope Island (Colman et al., 2002) suggests a continuous sedimentary record on the lake scale and low erosion. It is confirmed by sedimentological correlations, which indicate at least $4 \mathrm{~m}$ of sedimentary record above the tephra layer (estimated ca. $6.7 \mathrm{ka} \mathrm{BP}$ ) located stratigraphically above the salt deposits (Spencer et al., 1984). Thus, we conclude that the Holocene climatic optimum event remains the most probable phase during which deeper polygons and microbialitic fossil shorelines formed.

\section{Impact of tectonics on the distribution of the microbial deposits}

The spatial distribution of the microbial deposits and sedimentary structures can be an accurate proxy of the water level fluctuations through time and most of these fluctuations can be explained in the climatic record of the LB and GSL. However, the peculiar straight distribution of the Antelope Island microbialites along a sharp topographic fall (Fig. 5a, f) raises the question of whether tectonics may be an additional driver on the development and distribution of microbial deposits. The topographic fall is interpreted as a major fault belonging to the GSL complex fault system with a N-S to NW-SE orientation (Clark et al., 2014). The scattered lens-shaped detachments of microbial structures, which developed along the fault, were probably initiated by gliding (Fig. $5 \mathrm{~g}$ ). Gliding is commonly observed in an extensional context (e.g. passive margin) and reflects the response of the superficial sedimentary cover to extensional tectonics (Cobbold and Szatmari, 1991). Colman et al. (2002) reported the presence of possible microbial mound structures on seismic profiles located in the central area of the GSL, some of which are partly buried under Holocene sediments. Their occurrences were confirmed by geophysical prospects (CHIRP, sidescan sonar; Baskin et al., 2012). They formed on top of (sub-) vertical faults (Colman et al., 2002) or on structural microtopographic highs with onlapping sediments on the corresponding hanging wall lows (Baskin et al., 2012).

The tectonic framework in the Great Basin has led to significant groundwater fluxes, especially near the GSL (Cole, 1982). The contribution of hydrothermal and groundwater influxes is limited to $3 \%$ of the total water input but accounts for $18 \%$ of the total ionic influx (Hahl and Langford, 1964). The ion-rich groundwater could enhance the mineralization of the microbial structures. A similar relationship between fluid circulation and microbialite formation has already been observed in the East African Rift where microbialites (chimney stromatolites) were aligned along fractures and resulted from hydrothermal water input (Casanova, 1994). The presence of microbial deposits along the extended fault system in the GSL opens new perspectives with regard to the role of groundwater fluxes in microbialite mineralization processes. 


\section{Conclusions}

The Great Salt Lake is a modern hypersaline lake in which an extensive microbial system composed both of microbial mats and microbialites has developed. Detailed mapping of microbial, non-microbial and sedimentary structures along the western margin of Antelope Island using aerial images and field observations can be used to identify a specific nonrandom distribution of the microbial deposits and sedimentary structures. The microbial deposits cover ca. $90 \mathrm{~km}^{2}$ of the margin and show close relations with paleoshorelines or large-scale polygonal structures, as well as synsedimentary normal faults. These relations highlight the two main drivers on microbial deposit distribution in the Great Salt Lake:

i. Climate-driven water level fluctuations are evidenced here as a strong potential candidate to explain the distribution of the paleoshorelines and (desiccation) polygons associated with the microbialites. The available reconstructions of the lake levels allow us to estimate that almost all of the lowermost mapped paleoshorelines composed of coalescent microbial deposits may have developed ca. 3.6 and $2.9 \mathrm{ka} \mathrm{BP}$. Concerning the most extended and distal submersed desiccation polygons, they probably formed during a period of prolonged lowstand (Holocene climatic optimum ca. 6.9 and $6.0 \mathrm{kaBP}$ ). Climate appears therefore as a major driver of the GSL microbial deposits but cannot explain alone the main trends of microbial deposit distribution of the lake.

ii. Tectonics also plays a key role in this distribution, especially by the effects of synsedimentary normal faults.

The spatio-temporal distribution of the microbial deposits therefore appears to be a sensitive marker of environmental changes and tectonics. They can thus provide an additional tool to reconstruct paleoenvironmental and paleoclimatic changes on a regional scale. A closer observation of these microbial structures reveals a variety of mineral products (Mg clays, aragonite, dolomite) and fabrics. These features cannot only be explained by the external factors discussed above (e.g. climate and tectonics). The combination of observations of environmental conditions (e.g. hydrodynamics, substrate) as well as microbial and physicochemical parameters will eventually lead to an integrated conceptual model for the development, distribution and diversity of the GSL microbial deposits.

\section{Data availability}

This work is supported by data available in the literature (aerial and satellite images, maps, etc.) that are cited in the manuscript, as well as novel material collected by our team during successive field campaigns in the Great Salt
Lake. This material, comprising rock and biological (microbial mats) samples, processed powder for geochemistry, photographs, GIS maps etc., is accessible at the Biogéosciences laboratory at the University of Burgundy, 6 Boulevard Gabriel, 21000 Dijon, France.

\section{The Supplement related to this article is available online at doi:10.5194/bg-13-5511-2016-supplement.}

Acknowledgements. This work is a contribution to the SEDS team at the Biogéosciences Laboratory (Dijon, France) and Géoressources et Environnement team at the ENSEGID (Bordeaux, France). This study is also supported by funding provided by GDF Suez EP (ENGIE). We acknowledge John Luft and his colleagues from the Utah Division of Wildlife Resources for their help in the field and the boat provided to sample in the Great Salt Lake. We thank Fabien Garcia and Cédric Bougeault for the XRD analyses. We are grateful to the US Geological Survey, Google Earth, Utah Automated Geographic Reference Center, Garmin and Digitalglobe ${ }^{\circledR}$ for providing the aerial and satellite images used in this paper. We thank NASA and the USGS for providing the Landsat space images. These data are distributed by the Land Processes Distributed Active Archive Center (LP DAAC), located at USGS/EROS, Sioux Falls, SD, USA (http://lpdaac.usgs.gov).

Edited by: F. Wittmann

Reviewed by: four anonymous referees

\section{References}

Bahniuk Rumberlsperger, A. M.: Coupling Organic and Inorganic Methods to Study Growth and Diagenesis of Modern Microbial Carbonates, Rio de Janeiro State, Brazil: Implications for Interpreting Ancient Microbialite Facies Development, PhD, ETH Zurich, 2013.

Balch, D. P., Cohen, A. S., Schnurrenberger, D. W., Haskell, B. J., Valero Garces, B. L., Beck, J. W., Cheng, H., and Edwards, R. L.: Ecosystem and paleohydrological response to Quaternary climate change in the Bonneville Basin, Utah, Palaeogeogr. Palaeocl., 221, 99-122, 2005.

Baskin, R. L. and Allen, D. V.: Bathymetric Map of the South Part of Great Salt Lake, Utah, Scientific Investigations Map 2894, US Geological Survey, 2005.

Baskin, R. L., Driscoll, N., and Wright, V. P.: Lacustrine microbialites in Great Salt Lake: life in a dead lake, American Association of Petroleum Geologists Annual Convention Abstracts Volume, 13, 2011.

Baskin, R. L., Wright, V. P., Driscoll, N., Graham, K., and Hepner, G.: Microbialite Bioherms in Great Salt Lake: Influence of Active Tectonics and Anthropogenic Effects, 2012.

Baskin, R. L., Driscoll, N., and Wright, V. P.: Controls on lacustrine microbialite distribution in Great Salt Lake, Utah, Microbial Carbonates in Space and Time: Implications for Global Exploration and Production, 2013. 
Baumgartner, L. K., Spear, J. R., Buckley, D. H., Pace, N. R., Reid, R. P., Dupraz, C., and Visscher, P. T.: Microbial diversity in modern marine stromatolites, Highborne Cay, Bahamas, Environ. Microbiol., 11, 2710-2719, 2009.

Baxter, B., Litchfield, C., Sowers, K., Griffith, J., Dassarma, P., and Dassarma, S.: Microbial Diversity of Great Salt Lake, in: Adaptation to Life at High Salt Concentrations in Archaea, Bacteria, and Eukarya, edited by: Gunde-Cimerman, N., Oren, A., and Plemenitaš, A., Cellular Origin, Life in Extreme Habitats and Astrobiology, Springer Netherlands, 9-25, 2005.

Bouton, A., Vennin, E., Pace, A., Bourillot, R., Dupraz, C., Thomazo, C., Brayard, A., Désaubliaux, G., and Visscher, P. T.: External controls on the distribution, fabrics and mineralization of modern microbial mats in a coastal hypersaline lagoon, Cayo Coco (Cuba), Sedimentology, 63, 972-1016, 2016.

Burne, R. V. and Moore, L. S.: Microbialites; organosedimentary deposits of benthic microbial communities, PALAIOS, 2, 241254,1987

Carozzi, A. V.: Observations on Algal Biostromes in the Great Salt Lake, Utah, J. Geol., 70, 246-252, 1962.

Casanova, J.: Stromatolites from the East African Rift: A Synopsis, in: Phanerozoic Stromatolites II, edited by: Bertrand-Sarfati, J. and Monty, C., Springer Netherlands, 193-226, 1994.

Chidsey, T. C., Vanden Berg, M. D., and Eby, D. E.: Petrography and characterization of microbial carbonates and associated facies from modern Great Salt Lake and Uinta Basin's Eocene Green River Formation in Utah, USA, Geological Society, London, Special Publications, 2015.

Clark, D., L., Oviatt, C. G., and Dinter, D. A.: Interim Geologic Map of the East Part of the Tooele $30^{\prime} \times 60^{\prime}$ Quadrangle, Year 1 of 3, Utah Geological Survey Open-File Report 633, 2014.

Cobbold, P. R. and Szatmari, P.: Radial gravitational gliding on passive margins, Tectonophysics, 188, 249-289, 1991.

Cole, D. R.: Tracing Fluid Sources in the East Shore Area, Utah, Ground Water, 20, 586-593, 1982.

Colman, S. M., Kelts, K. R., and Dinter, D. A.: Depositional history and neotectonics in Great Salt Lake, Utah, from high-resolution seismic stratigraphy, Sediment. Geol., 148, 61-78, 2002.

Currey, D. R.: Coastal geomorphology of Great Salt Lake and vicinity, in: Great Salt Lake: a Scientific, Historical and Economic Overview, edited by: Gwynn, J. W., Utah Geological and Mineral Survey, Salt Lake City, Utah, 1980.

Currey, D. R. and James, S. R.: Paleoenvironments of the northeastern Great Basin and northeastern Basin rim region: a review of geological and biological evidence, in: Man and Environment in the Great Basin, edited by: Madsen, D. B. and O’Connel, J. F., Soc. American Archaeology Papers, 27-52, 1982.

Currey, D. R., Atwood, G., and Mabey, D. R.: Major levels of Great Salt Lake and Lake Bonneville, Utah Geological and Mineral Survey map 73, 1984.

Davison, I.: Geology and tectonics of the South Atlantic Brazilian salt basins, Geological Society, London, Special Publications, 272, 345-359, 2007.

Decho, A.: Exopolymer Microdomains as a Structuring Agent for Heterogeneity Within Microbial Biofilms, in: Microbial Sediments, edited by: Riding, R. and Awramik, S., Springer Berlin Heidelberg, 9-15, 2000.

Della Porta, G.: Carbonate build-ups in lacustrine, hydrothermal and fluvial settings: comparing depositional geometry, fabric types and geochemical signature, Geological Society, London, Special Publications, 418, 17-68, 2015.

Dupraz, C., Reid, R. P., Braissant, O., Decho, A. W., Norman, R. S., and Visscher, P. T.: Processes of carbonate precipitation in modern microbial mats, Earth-Sci. Rev., 96, 141-162, 2009.

Dupraz, C., Reid, R. P., and Visscher, P.: Microbialites, Modern, in: Encyclopedia of Geobiology, edited by: Reitner, J. and Thiel, V., Encyclopedia of Earth Sciences Series, Springer Netherlands, 617-635, 2011.

Eardley, A. J.: Sediments of Great Salt Lake, Utah, AAPG Bull., 22, 1305-1411, 1938.

Felton, A., Jewell, P. W., Chan, M., and Currey, D. R.: Controls of tufa development in Pleistocene Lake Bonneville, Utah, 3, University of Chicago Press, Chicago, Il, USA, 2006.

Gerdes, G.: Structures left by modern microbial mats in their host sediments, in: Atlas of Microbial Mat Features Preserved within the Siliciclastic Rock Record, edited by: Schieber, J., Bose, P., Eriksson, P. G., Banerjee, S., Sarkar, S., Altermann, W., and Catuneanu, O., Elsevier, 5-38, 2007.

Godsey, H. S., Currey, D. R., and Chan, M. A.: New evidence for an extended occupation of the Provo shoreline and implications for regional climate change, Pleistocene Lake Bonneville, Utah, USA, Quaternary Res., 63, 212-223, 2005.

Goslar, T., Czernik, J., and Goslar, E.: Low-energy 14C AMS in Poznan radiocarbon Laboratory, Poland, Nucl. Instrum. Meth. B, 223/224, 5-11, 2004

Gwynn, J. W.: Commonly asked questions about Utah's Great Salt Lake and ancient Lake Bonneville, Public Information Series, edited by: Survey, U. G., 22 pp., 1996.

Hahl, D. C. and Langford, R. H.: Dissolved-mineral inflow to Great Salt Lake and chemical characteristics of the Salt Lake brine, Part II: technical report, 40 pp., 1964.

Halley, R. B.: Ooid fabric and fracture in the Great Salt Lake and the geologic record, J. Sediment. Res., 47, 1099-1120, 1977.

Lall, U. and Mann, M.: The Great Salt Lake: A Barometer of LowFrequency Climatic Variability, Water Resour. Res., 31, 25032515, 1995.

Ley, R. E., Harris, J. K., Wilcox, J., Spear, J. R., Miller, S. R., Bebout, B. M., Maresca, J. A., Bryant, D. A., Sogin, M. L., and Pace, N. R.: Unexpected diversity and complexity of the Guerrero Negro hypersaline microbial mat, Appl. Environ. Microbiol., 72, 3685-3695, 2006.

Lindsay, M. R., Anderson, C., Fox, N., Scofield, G., Allen, J., Anderson, E., Bueter, L., Poudel, S., Sutherland, K., MunsonMcGee, J. H., Van Nostrand, J. D., Zhou, J., Spear, J. R., Baxter, B. K., Lageson, D. R., and Boyd, E. S.: Microbialite response to an anthropogenic salinity gradient in Great Salt Lake, Utah, Geobiology, in press, 2016.

Liu, M.: Cenozoic extension and magmatism in the North American Cordillera: the role of gravitational collapse, Tectonophysics, 342, 407-433, 2001.

McKenzie, J. A. and Eberli, G., P.: Late Holocene lake-level fluctuations of the Great salt Lake (Utah) as deduced form oxygenisotope and carbonate contents of cored sediments, Problems of and prospects for predicting Great Salt Lake levels, Salt Lake City, Utah, 1985.

Mello, M. R., De Azambuja Filho, N. C., Bender, A. A., Barbanti, S. M., Mohriak, W., Schmitt, P., and De Jesus, C. L. C.: The Namibian and Brazilian southern South Atlantic petroleum systems: are 
they comparable analogues?, Geological Society, London, Special Publications, 369, 249-266, 2012.

Murchison, S. B.: Fluctuation history of Great Salt Lake, Utah, during the last 13,000 Years, PhD, Department of geography, University of Utah, Salt Lake City, 157 pp., 1989.

Neal, J. T., Langer, A. M., and Kerr, P. F.: Giant Desiccation Polygons of Great Basin Playas, Geol. Soc. Am. Bull., 79, 69-90, 1968.

Nichols, G.: Sedimentology and Stratigraphy, 2nd Edn., WileyBlackwell, 432 pp., 2009.

Oviatt, C. G.: The Gilbert episode in the Great Salt Lake Basin, Utah, Miscellaneous publications, Utah Geological Survey, 20 pp., 2014.

Oviatt, C. G.: Chronology of Lake Bonneville, 30,000 to 10,000 yr BP, Quaternary Sci. Rev., 110, 166-171, 2015.

Oviatt, C. G., Currey, D. R., and Sack, D.: Radiocarbon chronology of Lake Bonneville, Eastern Great Basin, USA, Palaeogeogr. Palaeocl., 99, 225-241, 1992.

Pace, A., Bourillot, R., Bouton, A., Vennin, E., Galaup, S., Bundeleva, I., Patrier, P., Dupraz, C., Thomazo, C., Sansjofre, P., Yokoyama, Y., Franceschi, M., Anguy, Y., Pigot, L., Virgone, A., and Visscher, P. T.: Microbial and diagenetic steps leading to the mineralization of Great Salt Lake microbialites, Sci. Rep., 6, 31495, doi:10.1038/srep31495, 2016.

Patrickson, S. J., Sack, D., Brunelle, A. R., and Moser, K. A.: Late Pleistocene to early Holocene lake level and paleoclimate insights from Stansbury Island, Bonneville Basin, Utah, Quaternary Res., 73, 237-246, 2010.

Paull, C. K., Neumann, A. C., Bebout, B., Zabielski, V., and Showers, W.: Growth rate and stable isotopic character of modern stromatolites from San Salvador, Bahamas, Palaeogeogr. Palaeocl., 95, 335-344, 1992.

Pedone, V. A. and Folk, R. L.: Formation of aragonite cement by nannobacteria in the Great Salt Lake, Utah, Geology, 24, 763765, 1996.

Pierre, C., Ortlieb, L., and Person, A.: Supratidal evaporitic dolomite at Ojo de Liebre Lagoon, mineralogical and isotopic arguments for primary crystallization, J. Sediment. Res., 54, 10491061, 1984.

Post, F. J.: Biology of the North Arm, in: Great Salt Lake - A Scientific, Historical and Economic Overview, edited by: Gwynn, J. W., Utah, Geological and Mineral Survey, Bulletins, 313-321, 1980.
Ross, D. S.: Holocene fluctuations of Great Salt Lake, with special reference to evidence from the Eastern Shore, M.S. Thesis, University of Utah, 1973.

Rudy Jr, R. C.: Holocene fluctuations of Great Salt Lake, with special reference to evidence from the Western Shore, M.S. thesis, University of Utah, 1973.

Rupke, A. and McDonald, A.: Great Salt Lake brine chemistry database, 1966-2011, Utah Geological Survey Open-File Report 596, 2012.

Spencer, R., Baedecker, M. J., Eugster, H. P., Forester, R. M., Goldhaber, M. B., Jones, B. F., Kelts, K., McKenzie, J., Madsen, D. B., Rettig, S. L., Rubin, M., and Bowser, C. J.: Great Salt Lake, and precursors, Utah: The last 30,000 years, Contr. Mineral. Petrol., 86, 321-334, 1984.

Stal, L. J., van Gemerden, H., and Krumbein, W. E.: Structure and development of a benthic marine microbial mat, FEMS Microbiol. Lett., 31, 111-125, 1985.

Street, F. A. and Grove, A. T.: Global maps of lake-level fluctuations since 30,000 yr B.P, Quaternary Res., 12, 83-118, 1979.

van Gemerden, H.: Microbial mats: A joint venture, Mar. Geol., 113, 3-25, 1993.

Vasconcelos, C., McKenzie, J. A., Bernasconi, S., Grujic, D., and Tiens, A. J.: Microbial mediation as a possible mechanism for natural dolomite formation at low temperatures, Nature, 377, 220-222, 1995.

Wang, S. Y. and Gillies, R. R.: Climatology of the U.S. InterMountain West, in: Modern Climatology, edited by: Wang, S. Y., InTech, 2012.

Warren, J. K.: Evaporites: Sediments, Resources and Hydrocarbons, Springer, New York, 1035 pp., 2006.

Yamane, M., Yokoyama, Y., Miyairi, Y., Suga, H., Matsuzaki, H., Dunbar, R. B., and Ohkouchi, N.: Compound-Specific ${ }^{14} \mathrm{C}$ Dating of IODP Expedition 318 Core U1357A Obtained off the Wilkes Land Coast, Antarctica, Radiocarbon, 56, 1009-1017, 2014.

Yokoyama, Y., Miyairi, Y., Matsuzaki, H., and Tsunomori, F.: Relation between acid dissolution time in the vacuum test tube and time required for graphitization for AMS target preparation, Nucl. Instrum. Meth. B, 259, 330-334, 2007.

Yokoyama, Y., Koizumi, M., Matsuzaki, H., Miyairi, Y., and Ohkouchi, N.: Developing Ultra Small-Scale Radiocarbon Sample Measurement at the University of Tokyo, Radiocarbon, 52, 310318, 2010. 